\title{
Differential effects of dietary whey, casein and soya on colonic DNA damage and large bowel SCFA in rats fed diets low and high in resistant starch
}

\author{
Shusuke Toden ${ }^{1,2}$, Anthony R. Bird ${ }^{1}$, David L. Topping ${ }^{1}$ and Michael A. Conlon ${ }^{1 *}$ \\ ${ }^{1}$ Food Futures National Research Flagship, CSIRO Human Nutrition, PO Box 10041, Adelaide BC SA 5000, Australia \\ ${ }^{2}$ Discipline of Physiology, School of Molecular Science, University of Adelaide, Adelaide, SA 5005, Australia
}

(Received 6 June 2006 - Revised 9 October 2006 - Accepted 10 October 2006)

\begin{abstract}
Feeding higher levels of dietary animal protein (as casein or red meat) increases colonic DNA damage and thins the colonic mucus barrier in rats. Feeding resistant starch (RS) reverses these changes and increases large bowel SCFA. The present study examined whether high dietary dairy (casein or whey) or plant (soya) proteins had similar adverse effects and whether dietary RS was protective. Adult male rats were fed diets containing 15 or $25 \%$ casein, whey or soya protein with or without $48 \%$ high amylose starch (as a source of RS) for 4 weeks. DNA damage was measured in isolated colonocytes using the comet assay. Higher dietary casein and soya (but not whey) increased colonocyte DNA damage. DNA damage was highest with soya when fed at 15 or $25 \%$ protein without RS. Dietary RS attenuated protein-induced colonocyte DNA damage in all groups but it remained significantly higher in rats fed $25 \%$ soya compared with those fed $15 \%$ protein. Dietary protein level did not affect colonic mucus thickness overall but the barrier was thinner in rats fed high dietary casein. This effect was reversed by feeding RS. Caecal total SCFA and butyrate pools were higher in rats fed RS compared with digestible starch. Caecal and faecal SCFA were unrelated to genetic damage but correlated with mucus thickness. The present data confirm that higher dietary protein affected colonocyte DNA and colonic mucus thickness adversely but that proteins differ in their effects on these indices of colon health. The data show also that these changes were reversed by RS.
\end{abstract}

Casein: Whey protein: Soya protein: Resistant starch: Colonic genotoxicity

Diet is implicated strongly in the pathogenesis of serious large bowel diseases. Recent large population studies have found that high intakes of red and/or processed meat are positive risk factors of colo-rectal cancer (Cassidy et al. 1994; Rieger et al. 1999; Norat et al. 2002, 2005; Chao et al. 2005; Larsson et al. 2005). The components of these meatbased foods responsible for increased risk remain to be established. It has been suggested that minor meat components such as haem iron contribute to this increased risk. In a meta-analysis of prospective population studies, Cassidy et al. (1994) identified dietary protein per se as an independent risk factor for colo-rectal cancer. High protein intakes have other adverse effects on bowel health as evidenced by an increased likelihood of relapse for ulcerative colitis patients (Jowett et al. 2004). Inflammatory bowel disease is a risk factor for large bowel cancer (Chen et al. 2005), supporting a role for the protein component in disease aetiology.

We have shown previously that high dietary levels of animal-derived proteins (casein and red meat) increased colonocyte DNA damage in rats (Toden et al. 2005, 2006). Genomic damage is a prerequisite for cancer and the data could help to explain the associations between the consumption of red meat and meat products and large bowel cancer (Norat et al. 2005). Both protein types also induced a thinning of the mucus barrier in the colon which could be a potential contributory factor in inflammatory bowel disease
(Shaoul et al. 2004). However, the fact that high dietary levels of casein had the same effects as red meat suggest that the effect was not specific to one type of protein. Our knowledge of the role of dietary proteins in cancer aetiology in general is poor and it remains to be established whether other protein types have similar effects. For example, whey protein consumption is generally regarded as being protective against experimental colo-rectal cancer (Belobrajdic et al. 2003; Xiao et al. 2005) and also can reduce aberrant crypt foci compared with other protein types (McIntosh \& Le Leu, 2001; Belobrajdic et al. 2003). However, it is not known whether its actions are affected by dietary inclusion level. The situation with soya is confused with several contradictory experimental studies on colon cancer risk and soya protein consumption (Govers et al. 1993; McIntosh et al. 1995; Hakkak et al. 2001b; Badger et al. 2005). Isoflavones and other phytochemicals are often present in soya-based products and have been shown to inhibit cancer cell growth and induce apoptosis (Hakkak et al. 2001b). However, several rodent studies showed that soyabean protein increased colo-rectal cancer risk, induced damage to the colonic epithelium and stimulated colonocyte proliferation when compared with a casein diet (Govers et al. 1993; McIntosh et al. 1995). Soya protein isolates have been investigated extensively also for their ability to lower plasma cholesterol relative to casein (Lin et al. 2004), again suggesting some differences in nutritional properties. 
Intake of fruits, vegetables and grains is linked to reduction of colo-rectal cancer risk (Potter et al. 1993; Giovannucci \& Willett, 1994; Steinmetz \& Potter, 1996). These foods contain non-starch polysaccharides (NSP; major components of dietary fibre) which are thought to contribute to their protective action. Many also contain resistant starch (RS) which can also contribute to their protective effect (Topping \& Clifton, 2001). RS is that fraction of starch which enters the large bowel undigested (Englyst et al. 1982) and increases colonic fermentation and large bowel and faecal SCFA concentrations (Cummings \& Macfarlane, 1991). Butyrate, a major SCFA, is the preferred energy source of colonocytes (Clausen \& Mortensen, 1995; Ritzhaupt et al. 1998) and appears to provide protection against activities associated with carcinogenesis (Lupton, 1995). Furthermore, epidemiological studies have related a reduced risk of colon cancer to increased consumption of starch (Cassidy et al. 1994; Bingham et al. 2003). Our previous studies (Toden et al. 2005, 2006) also showed that dietary RS protected against casein and red meat-induced colonic DNA damage and some loss of the mucosal barrier. The previous findings provide support for a role of RS in maintaining colonic integrity and lowering the risk of serious large bowel disease. However, not all experimental studies support the protective effects of RS. One study reported that lipid peroxidation-induced DNA damage was increased in colonic mucosa of health subjects when they were fed the high RS diets (Wacker et al. 2002). Another study showed that RS increased intestinal tumour formation of Apc1638N mouse model compared with those fed the control diets (Williamson et al. 1999).

The question of the differential effects of animal and plant proteins is an important one and remains open. In the present study, we have sought to examine the effects of three different types of dietary proteins, casein, whey and soya, on colonic DNA damage, colonic mucus barrier thickness and SCFA levels in the caecum and faeces of rats. In addition, we have examined the ability of dietary RS to modulate the effects of changes in the colon induced by these proteins.

\section{Materials and methods}

\section{Animals and diets}

Adult male Sprague-Dawley rats ( $n$ 96) weighing approximately $200 \mathrm{~g}$ were obtained from the Animal Resource Centre, Murdoch University, Perth, Western Australia. Rats were housed in wire-bottomed cages in a room with controlled heating and lighting $\left(20-23^{\circ} \mathrm{C}\right.$ with a $12 \mathrm{~h}$ light-dark cycle) and had free access to food and water. They were allocated randomly to twelve groups (eight per group) and fed one of twelve diets (Table 1) for 4 weeks. Each cage had a ceramic bowl to ensure that the animals had access to a surface other than wire mesh.

The diets, which were based on the AIN-93G diet formulation, contained 15 or $25 \%$ casein (New Zealand Milk, Auckland, New Zealand), whey isolate (Balance Muscle Technologies, Auckland, New Zealand) and soya isolate (Phyto Foods Australia Pty Ltd, NSW, Australia), with or without $48 \%$ high amylose maize starch (Hi-maize ${ }^{\mathrm{TM}}$; National Starch and Chemical Company, Sydney, NSW, Australia) as a source of RS. Diets without high amylose starch contained highly digestible starch

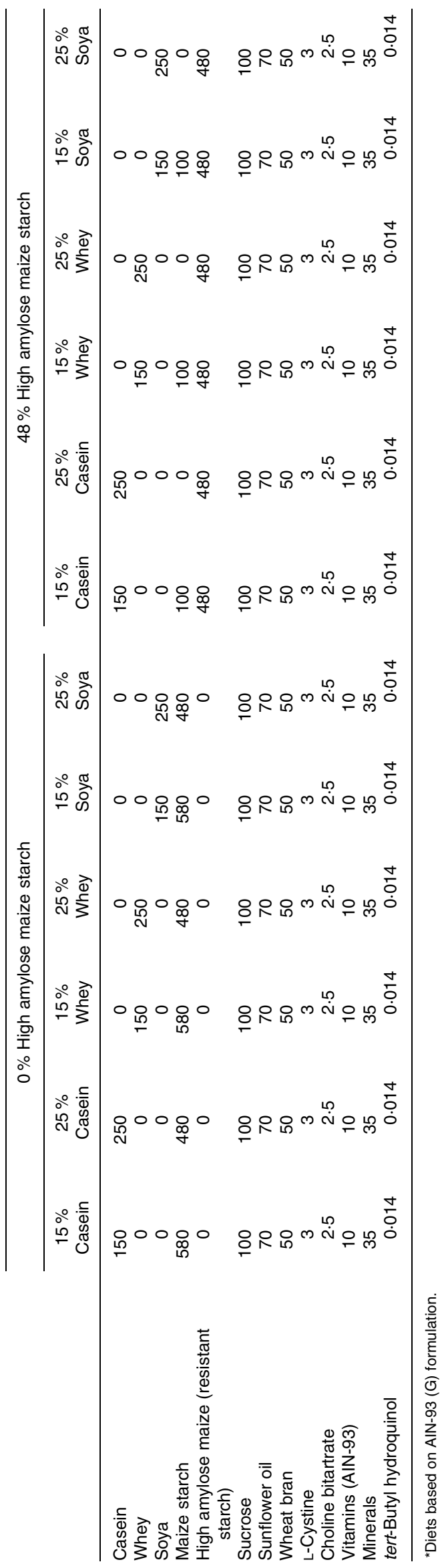


(Cornstarch 3401C; National Starch and Chemical Company). All diets contained $5 \%$ wheat bran as the fibre source.

All procedures involving animals were approved by the Commonwealth Scientific and Industrial Research Organisation (CSIRO) Health Sciences and Nutrition Animal Ethics Committee and the University of Adelaide Animal Ethics Committee and conformed to published guidelines (National Health and Medical Research Council, 2004).

\section{Sampling procedures}

In the final $4 \mathrm{~d}$ of the experiment rats were placed in metabolic cages to collect faecal output. At the conclusion of the study the rats were anaesthetized with $4 \%$ halothane/oxygen and gut tissues and digesta were collected as described previously (Toden et al. 2005). Faecal and caecal digesta samples were frozen for subsequent analyses.

\section{Comet assay}

A $6 \mathrm{~cm}$ segment of colon was removed from each rat at a point $3 \mathrm{~cm}$ from the most distal end of the colon and colonocytes were isolated immediately. These cells were used for the measurement of DNA strand breaks using the single-cell gel electrophoresis (comet) assay as described previously (Anderson et al. 1999). Comet tail moment is the product of tail length and the fraction of DNA in the tail and was calculated for fifty cells from each of three slides per rat. Tail moment was calculated by Scion Image Beta 4.02 image processing and analysis software (Scion Corp., Frederick, MD, USA) using a public domain macro (Helma \& Uhl, 2000).

\section{Colonic mucus layer thickness}

A $1 \mathrm{~cm}$ segment of colon was removed from each rat at a point $2 \mathrm{~cm}$ from the most distal end of the colon and cut open along the anti-mesenteric ridge and the mucosal surface was washed gently with $0 \cdot 15 \mathrm{M}-\mathrm{NaCl}$ solution to remove digesta. The thickness of mucus lining the colon was determined by further cutting the tissue into $1.6 \mathrm{~mm}$ lengths, illuminating the tissue segments, capturing numerous images of the mucus layer along each segment, and then measuring the thickness using an image analysis program as described previously (Toden et al. 2005). For each animal, ten measurements were taken at different points along four tissue segments to give forty thickness measurements in total.

\section{$S C F A$}

Faecal and caecal contents were thawed then distilled and homogenised with $20 \mu \mathrm{l} 1.68 \mathrm{~mm}$-heptanoic acid (internal standard). The contents were analysed for SCFA (acetic, propionic and butyric acids), in duplicate, using an Agilent Technologies 6890N Network Gas Chromatograph System fitted with a Zebron ZB-FFAP column $(0.53 \mathrm{~mm} \times 30 \mathrm{~m})$ (Phenomenex, Torrance, CA, USA) as described previously (Patten et al. 2002).

\section{Statistical analyses}

Data are presented as means and their standard errors for each treatment group except in tables (where they are presented with pooled standard error values). The effect of RS and protein, and their interactions, were determined by three-way ANOVA and differences between treatments were analysed post hoc by Tukey's test. The relationship between caecal and faecal variables, colonic DNA damage and mucus layer thickness was determined by regression analysis. Data underwent logarithmic transformation when needed. Analyses were performed using a Statistical Analysis Systems statistical software program (version 8.02: SAS Institute, Cary, NC, USA). A value of $P<0.05$ was used as the criterion of significance.

\section{Results}

Body weight gain and daily food and water intakes

The mean initial live weight for all groups combined was 241 (SEM 2) g. Neither live weight gain (data not shown) nor final body weight differed between the experimental diets (mean final weight 353 (SEM 4) g) over the 4-week study. There was no effect of protein type, protein level or RS on the daily food intake of the animals (Table 2). Neither RS nor protein type affected water intake but there was an independent effect of protein type and an interactive effect of protein level and type on daily water intake (both $P<0.05$ ). Water consumption was highest in rats fed the $25 \%$ soya diet.

\section{Caecal content and tissue weights, faecal and urine output, intestinal weight and length}

The wet weight of caecal content in RS-fed rats was $5 \cdot 1$ times higher than those fed standard starch $(P<0.001$; Table 2). There was also a significant interaction between protein type and RS. Caecal tissue weight was unaffected by protein type or level but was significantly greater in rats fed RS (Table 2). There was also an interaction between dietary protein type and RS with a significantly lower weight in rats fed $25 \%$ whey and RS compared with the other groups fed RS. Caecal digesta $\mathrm{pH}$ values were greater than 7 in all rats fed the standard starch diets with the exception of those fed the $25 \%$ soya diet (Table 2). There was a small effect of protein type (but not level) on $\mathrm{pH}$ and a significant interaction between protein type and level and between these effects and RS.

Faecal output was unaffected by dietary protein level but was significantly higher in all groups of rats fed RS (Table 2). The type of dietary protein interacted with RS with a significantly lower output of faeces in rats fed $25 \%$ casein with RS compared with other groups fed the high RS diet. The $\mathrm{pH}$ of faeces followed the same trend as the caecal values (i.e. $>7$ ) in rats fed the low RS diet with significantly greater acidity in rats fed RS. There were effects of protein level and type with the highest $\mathrm{pH}$ (close to 8) in rats fed whey and standard starch.

Daily urine output was unaffected by RS (Table 2) but was affected significantly by protein level with higher outputs in all groups fed $25 \%$ protein.

There were increases in both weight and length of the colon and small intestine when rats were fed the RS compared to those on diets without RS (all $P<0.001$; Table 3). However, protein type did not influence weight or length of either the colon or small intestine independently, but did interact significantly with RS. 
Table 2. Effects of dietary casein, whey, soya and high amylose starch maize (resistant starch, RS) levels on daily food and water intakes, faecal and urinary outputs, and caecal and faecal measure-

(Mean values with their the pooled standard error, $n 8$ )

\begin{tabular}{|c|c|c|c|c|c|c|c|c|c|c|c|c|c|c|c|c|c|c|c|c|}
\hline & \multicolumn{12}{|c|}{ Dietary treatment } & \multirow[b]{3}{*}{$\begin{array}{l}\text { Pooled } \\
\text { SEM }\end{array}$} & \multirow{2}{*}{\multicolumn{7}{|c|}{ Main effects ( $P$ values) }} \\
\hline & \multicolumn{6}{|c|}{$0 \%$ High amylose maize starch } & \multicolumn{6}{|c|}{$48 \%$ High amylose maize starch } & & & & & & & & \\
\hline & $\begin{array}{c}15 \% \\
\text { Casein }\end{array}$ & $\begin{array}{c}25 \% \\
\text { Casein }\end{array}$ & $\begin{array}{l}15 \% \\
\text { Whey }\end{array}$ & $\begin{array}{l}25 \% \\
\text { Whey }\end{array}$ & $\begin{array}{l}15 \% \\
\text { Soya }\end{array}$ & $\begin{array}{l}25 \% \\
\text { Soya }\end{array}$ & $\begin{array}{l}15 \% \\
\text { Casein }\end{array}$ & $\begin{array}{l}25 \% \\
\text { Casein }\end{array}$ & $\begin{array}{l}15 \% \\
\text { Whey }\end{array}$ & $\begin{array}{l}25 \% \\
\text { Whey }\end{array}$ & $\begin{array}{l}15 \% \\
\text { Soya }\end{array}$ & $\begin{array}{l}25 \% \\
\text { Soya }\end{array}$ & & RS level & $\begin{array}{l}\text { Protein } \\
\text { type }\end{array}$ & $\begin{array}{c}\text { Protein } \\
\text { level }\end{array}$ & $\begin{array}{r}\text { Protein type } \times \\
\text { Protein level }\end{array}$ & $\begin{array}{c}\text { Protein } \\
\text { type } \times \text { RS }\end{array}$ & $\begin{array}{c}\text { Protein } \\
\text { level } \times \text { RS }\end{array}$ & All \\
\hline Food intake $(\mathrm{g} / \mathrm{d})$ & $17 \cdot 2^{\mathrm{a}}$ & $18 \cdot 7^{\mathrm{ab}}$ & $17.9^{\mathrm{ab}}$ & $17 \cdot 3^{\mathrm{a}}$ & $18 \cdot 1^{\text {ab }}$ & $17 \cdot 2^{\mathrm{a}}$ & $19 \cdot 1^{\mathrm{b}}$ & $17 \cdot 1^{\mathrm{a}}$ & $19 \cdot 3^{\mathrm{b}}$ & $17.8^{\mathrm{ab}}$ & $17.4^{\mathrm{b}}$ & $17 \cdot 8^{\mathrm{ab}}$ & 0.6 & 0.32 & 0.54 & 0.14 & 0.48 & 0.52 & 0.15 & $<0.05$ \\
\hline Water intake $(\mathrm{m} / \mathrm{d})$ & $18 \cdot 0^{\mathrm{a}}$ & $23.0^{\mathrm{a}}$ & $20 \cdot 0^{\mathrm{a}}$ & $24 \cdot 2^{\mathrm{a}}$ & $21 \cdot 3^{\mathrm{a}}$ & $24 \cdot 5^{\mathrm{a}}$ & $22 \cdot 6^{\mathrm{a}}$ & $24 \cdot 3^{\mathrm{a}}$ & $22 \cdot 8^{\mathrm{a}}$ & $26 \cdot 8^{\mathrm{b}}$ & $20.7^{\mathrm{a}}$ & $35.7^{\mathrm{c}}$ & 1.8 & 0.06 & 0.29 & $<0.05$ & $<0.05$ & 0.26 & 0.46 & 0.23 \\
\hline \multicolumn{21}{|l|}{ Caecal measurements } \\
\hline Contents weight (g) & $0.8^{\mathrm{a}}$ & $1.0^{\mathrm{a}}$ & $0.9^{\mathrm{a}}$ & $1.3^{\mathrm{a}}$ & $1 \cdot 1^{\mathrm{a}}$ & $2 \cdot 0^{\mathrm{a}}$ & $5.7^{\mathrm{b}}$ & $5 \cdot 6^{\mathrm{b}}$ & $6 \cdot 9^{\mathrm{b}}$ & $5.5^{\mathrm{b}}$ & $6 \cdot 1^{\mathrm{b}}$ & $5 \cdot 6^{\mathrm{b}}$ & 0.4 & $<0.001$ & 0.36 & 0.63 & 0.4 & $<0.001$ & 0.47 & 0.46 \\
\hline Tissue weight (g) & $1.0^{\mathrm{a}}$ & $1 \cdot 2^{\mathrm{a}}$ & $1 \cdot 2^{\mathrm{a}}$ & $1 \cdot 1^{\mathrm{a}}$ & $1 \cdot 1^{\mathrm{a}}$ & $1.5^{\mathrm{a}}$ & $3.9^{\mathrm{bc}}$ & $4 \cdot 1^{\mathrm{c}}$ & $3.7^{\mathrm{bc}}$ & $2 \cdot 8^{\mathrm{d}}$ & $3.0^{\mathrm{bd}}$ & $3.5^{\mathrm{bc}}$ & 0.2 & $<0.001$ & 0.34 & 0.88 & 0.3 & $<0.001$ & 0.58 & 0.50 \\
\hline $\mathrm{pH}$ & $7.77^{\mathrm{a}}$ & $7.57^{\mathrm{a}}$ & $7.84^{\mathrm{a}}$ & $7.89^{\mathrm{a}}$ & $7 \cdot 31^{a}$ & $6.56^{\mathrm{c}}$ & $6.03^{\mathrm{bc}}$ & $5 \cdot 68^{\mathrm{b}}$ & $5 \cdot 84^{\mathrm{b}}$ & $5.83^{\mathrm{b}}$ & $6 \cdot 16^{\mathrm{bc}}$ & $5 \cdot 60^{\mathrm{b}}$ & 0.29 & $<0.001$ & $<0.05$ & 0.96 & $<0.001$ & $<0.001$ & 0.53 & 0.76 \\
\hline \multicolumn{21}{|l|}{ Faecal measurements } \\
\hline Output (g/d) & $1.9^{\mathrm{a}}$ & $1.9^{\mathrm{a}}$ & $2 \cdot 4^{a}$ & $2 \cdot 3^{\mathrm{a}}$ & $2 \cdot 3^{\mathrm{a}}$ & $2 \cdot 4^{\mathrm{a}}$ & $4.8^{\mathrm{bc}}$ & $3.7^{\mathrm{d}}$ & $5 \cdot 1^{\mathrm{b}}$ & $4.6^{c}$ & $4.9^{\mathrm{bc}}$ & $5 \cdot 6^{\mathrm{b}}$ & 0.2 & $<0.001$ & $<0.05$ & 0.32 & $<0.05$ & $<0.001$ & 0.33 & 0.11 \\
\hline $\mathrm{pH}$ & $7 \cdot 31^{\mathrm{a}}$ & $7.22^{\mathrm{a}}$ & $7.91^{\mathrm{C}}$ & $8.09^{\mathrm{c}}$ & $7.02^{\mathrm{a}}$ & $7 \cdot 24^{a}$ & $5 \cdot 60^{\mathrm{b}}$ & $5.81^{\mathrm{b}}$ & $5 \cdot 75^{\mathrm{b}}$ & $5 \cdot 56^{\mathrm{b}}$ & $5 \cdot 83^{b}$ & $5 \cdot 67^{b}$ & 0.40 & $<0.001$ & $<0.001$ & $<0.05$ & 0.03 & $<0.001$ & 0.16 & 0.60 \\
\hline Urine output (ml/d) & $8 \cdot 3^{\mathrm{a}}$ & $12 \cdot 0^{\mathrm{b}}$ & $9 \cdot 4^{a e}$ & $11 \cdot 4^{\mathrm{b}}$ & $10 \cdot 0^{\mathrm{e}}$ & $12.4^{\mathrm{b}}$ & $8 \cdot 6^{\mathrm{a}}$ & $12 \cdot 2^{\mathrm{b}}$ & $9 \cdot 3^{\mathrm{ae}}$ & $13.5^{d}$ & $9 \cdot 0^{\mathrm{ae}}$ & $13 \cdot 7^{d}$ & 0.90 & 0.42 & 0.26 & $<0.001$ & $<0.001$ & 0.78 & 0.16 & 0.73 \\
\hline
\end{tabular}

${ }^{\mathrm{a}-\mathrm{e}}$ Mean values within a row with unlike superscript letters were significantly different $(P<0.05)$.

${ }^{\star}$ For details of procedures, see p. 537. Data were analysed by three-way ANOVA and post hoc analysis by Tukey's test.

Table 3. Effects of dietary casein, whey, soya and high amylose starch maize (resistant starch, RS) levels on length and weight of the colon and small intestine and weight of colonic contents in rats* (Mean values with their pooled standard error, $n 8$ )

\begin{tabular}{|c|c|c|c|c|c|c|c|c|c|c|c|c|c|c|c|c|c|c|c|c|}
\hline & \multicolumn{12}{|c|}{ Dietary treatment } & \multirow[b]{3}{*}{$\begin{array}{l}\text { Pooled } \\
\text { SEM }\end{array}$} & \multirow{2}{*}{\multicolumn{7}{|c|}{ Main effects ( $P$ values) }} \\
\hline & \multicolumn{6}{|c|}{$0 \%$ High amylose maize starch } & \multicolumn{6}{|c|}{$48 \%$ High amylose maize starch } & & & & & & & & \\
\hline & $\begin{array}{c}15 \% \\
\text { Casein }\end{array}$ & $\begin{array}{c}25 \% \\
\text { Casein }\end{array}$ & $\begin{array}{l}15 \% \\
\text { Whey }\end{array}$ & $\begin{array}{l}25 \% \\
\text { Whey }\end{array}$ & $\begin{array}{l}15 \% \\
\text { Soya }\end{array}$ & $\begin{array}{l}25 \% \\
\text { Soya }\end{array}$ & $\begin{array}{l}15 \% \\
\text { Casein }\end{array}$ & $\begin{array}{c}25 \% \\
\text { Casein }\end{array}$ & $\begin{array}{l}15 \% \\
\text { Whey }\end{array}$ & $\begin{array}{l}25 \% \\
\text { Whey }\end{array}$ & $\begin{array}{l}15 \% \\
\text { Soya }\end{array}$ & $\begin{array}{l}25 \% \\
\text { Soya }\end{array}$ & & $\begin{array}{l}\text { RS } \\
\text { level }\end{array}$ & $\begin{array}{l}\text { Protein } \\
\text { type }\end{array}$ & $\begin{array}{c}\text { Protein } \\
\text { level }\end{array}$ & $\begin{array}{l}\text { Protein type } \times \\
\text { Protein Level }\end{array}$ & $\begin{array}{l}\text { Protein } \\
\text { type } \times \text { RS }\end{array}$ & $\begin{array}{c}\text { Protein } \\
\text { level } \times \text { RS }\end{array}$ & All \\
\hline \multicolumn{21}{|l|}{ Colon } \\
\hline Length $(\mathrm{cm})$ & $18.4^{\mathrm{abc}}$ & $17 \cdot 4^{\text {acd }}$ & $16 \cdot 6^{\mathrm{bcd}}$ & $16 \cdot 1^{d}$ & $17.5^{\mathrm{abcd}}$ & $16 \cdot 4^{\text {cd }}$ & $18 \cdot 3^{\mathrm{abc}}$ & $c^{c} 18.8^{\mathrm{a}}$ & $18 \cdot 1^{\mathrm{a}}$ & $18 \cdot 5^{\mathrm{ab}}$ & $18 \cdot 6^{\mathrm{a}}$ & $18 \cdot 3^{\mathrm{abc}}$ & 0.7 & $<0.001$ & 0.21 & 0.40 & 0.51 & $<0.05$ & 0.22 & 0.92 \\
\hline Weight (g) & $1.08^{\mathrm{ab}}$ & $1 \cdot 11^{\mathrm{abcd}}$ & $1.04^{\mathrm{b}}$ & $0.98^{b}$ & $1.03^{\mathrm{b}}$ & $1.04^{\mathrm{ab}}$ & $1.35^{\mathrm{d}}$ & $1.34^{\mathrm{c}}$ & $1 \cdot 19^{\mathrm{abcd}}$ & $1.28^{\mathrm{acd}}$ & $1.41^{\mathrm{d}}$ & $1.39^{d}$ & 0.08 & $<0.001$ & 0.17 & 0.88 & 0.63 & $<0.001$ & 0.81 & 0.70 \\
\hline Content (g) & $0.55^{\mathrm{abc}}$ & $0.50^{\mathrm{ac}}$ & $0.27^{c}$ & $0.35^{\mathrm{c}}$ & $0.36^{\mathrm{c}}$ & $0.80^{\mathrm{abd}}$ & $1.01^{\mathrm{d}}$ & $0.86^{\mathrm{abd}}$ & $0.91^{\mathrm{abd}}$ & $0.94^{\mathrm{bd}}$ & $1 \cdot 10^{\mathrm{d}}$ & $0.88^{\text {abd }}$ & 0.10 & $<0.001$ & 0.25 & 0.73 & 0.53 & $<0.001$ & 0.12 & 0.29 \\
\hline \multicolumn{21}{|l|}{ Small intestine } \\
\hline Weight (g) & $7 \cdot 3^{\mathrm{a}}$ & $8 \cdot 1^{\text {ad }}$ & $8 \cdot 0^{\text {ad }}$ & $8.0^{\text {ad }}$ & $7 \cdot 7^{\mathrm{a}}$ & $7 \cdot 7^{\mathrm{a}}$ & $9 \cdot 7^{\mathrm{bc}}$ & $10 \cdot 0^{\mathrm{b}}$ & $9 \cdot 7^{\mathrm{bc}}$ & $9 \cdot 2^{\mathrm{bc}}$ & $8 \cdot 8^{\mathrm{cd}}$ & $10 \cdot 1^{\mathrm{b}}$ & 0.3 & $<0.001$ & 0.71 & 0.10 & 0.17 & $<0.001$ & 0.79 & $0 \cdot 10$ \\
\hline Length $(\mathrm{cm})$ & $106 \cdot 4^{\mathrm{a}}$ & $104 \cdot 6^{\mathrm{a}}$ & $102 \cdot 5^{\mathrm{a}}$ & $105 \cdot 3^{\mathrm{a}}$ & $107 \cdot 3^{\mathrm{a}}$ & $108 \cdot 4^{\mathrm{abc}}$ & $112.0^{\mathrm{bc}}$ & $110.5^{\mathrm{bc}}$ & $110 \cdot 6^{\mathrm{bc}}$ & $108 \cdot 8^{\mathrm{bc}}$ & $110.9^{b c}$ & $115.9^{\mathrm{b}}$ & 2.6 & $<0.001$ & 0.16 & 0.67 & 0.42 & $<0.05$ & 0.96 & 0.58 \\
\hline
\end{tabular}

${ }^{a-d}$ Mean values within a row with unlike superscript letters were significantly different $(P<0.05)$.

${ }^{*}$ For details of procedures, see p. 537. Data were analysed by three-way ANOVA and post hoc analysis by Tukey's test. 


\section{DNA damage}

The viability of colonocytes isolated for the comet assay was 92.2 (SEM 2.4) \% (all groups combined) and did not differ significantly between groups. When RS was absent from the diet, comet tail moments of isolated colonocytes were approximately twice as great for $25 \%$ casein diets compared with those for $15 \%$ casein diets $(P<0.001$; Fig. 1$)$. Similarly, the $25 \%$ soya diet increased the tail moment by $87 \%$ compared to the $15 \%$ soya diet $(P<0 \cdot 05)$. However, there was no significant difference between 15 and $25 \%$ whey diets which had tail moments similar to the $15 \%$ casein and soya groups. Overall, rats fed whey protein showed less colonic DNA damage compared to those fed casein or soya $(P<0 \cdot 001)$. Inclusion of $\mathrm{RS}$ in the diet lowered the level of colonic DNA damage for all three dietary groups $(P<0.001)$. Although RS reduced soya-induced colonic DNA damage, colonocyte comet tail moment of rats fed $25 \%$ soya with $\mathrm{RS}$ remained significantly greater than those fed the $15 \%$ soya diet.

\section{Colonic mucus layer thickness}

The colonic mucus layer was thicker in rats fed RS compared to those fed standard maize starch $(P<0.001)$. The $25 \%$ casein diet reduced colonic mucus layer thickness by $62 \%$ compared to the $15 \%$ casein diet in rats consuming low RS $(P<0.001)$, but there was no similar reduction of mucus thickness in rats fed the high soya and whey diets with low RS (Fig. 2). The inclusion of RS in the diet prevented the loss of mucus thickness induced by high casein. Regression analysis indicates that there is a significant inverse relationship

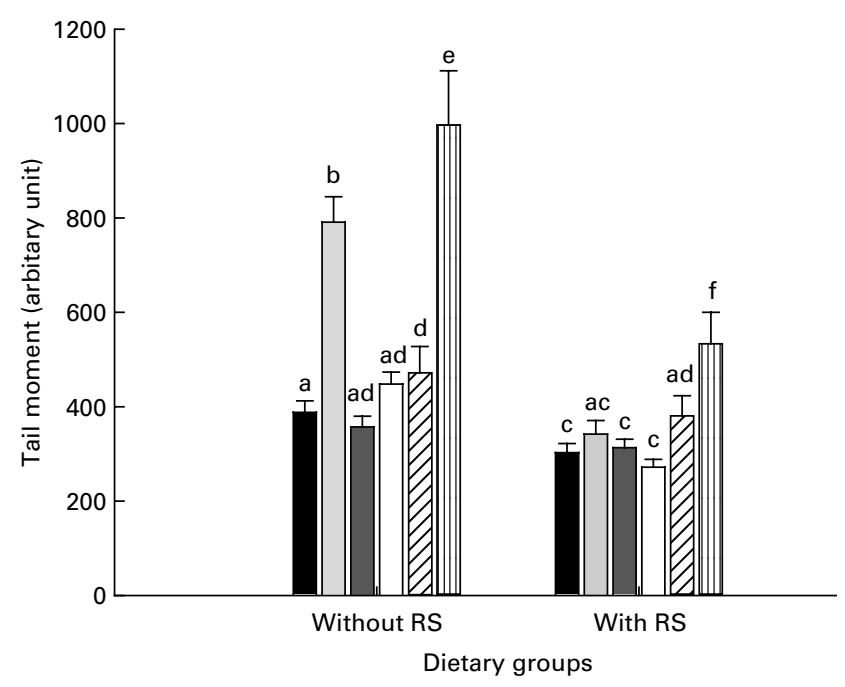

Fig. 1. Effects of dietary casein ( $\square, 15 \%$; $\square, 25 \%$ ), whey ( $\square, 15 \%$; $\square, 25 \%$ ), soya ( $\square, 15 \%$; 四, $25 \%$ ) and resistant starch (RS) levels on colonic genetic damage in rats. The comet assay was performed on colonocytes extracted from the colon and the resulting comet tail moments (comet tail length $\times \%$ DNA in the tail) are presented. For details of procedures, see p. 537. Values are means with their standard errors depicted by vertical bars $(n 8)$. ${ }^{a-f}$ Mean values with unlike superscript letters were significantly different $(P<0.05)$. Significant main effects of the dietary groups are RS level $(P<0.001)$, protein type $(P<0.001)$, protein level $(P<0.001)$, protein type $\times$ protein level $(P<0.01)$ and protein level $\times \operatorname{RS}(P<0.001)$.

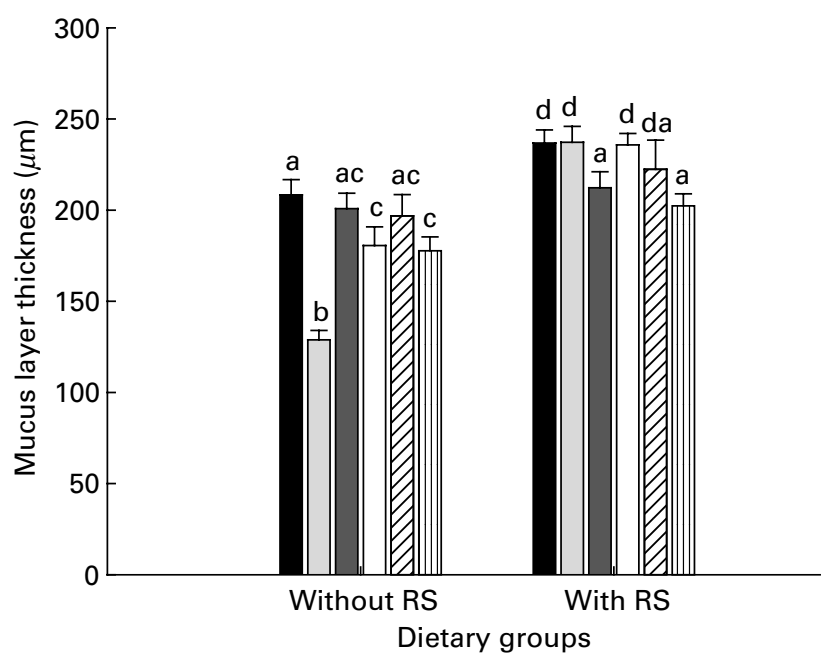

Fig. 2. Effects of dietary casein ( $\square, 15 \%$; $\mathbf{\square}, 25 \%$ ), whey ( $\square, 15 \%$; $\square$, $25 \%$ ), soya ( $\square, 15 \%$; 四, $25 \%$ ) and resistant starch levels on the thickness of the mucus lining the colon. For details of procedures, see p. 537 . Values are means with their standard errors depicted by vertical bars ( $n$ 8). ${ }^{a-d}$ Mean values with unlike superscript letters were significantly different $(P<0.05)$. Significant main effects of the dietary groups are RS level $(P<0.001)$, protein type $\times \mathrm{RS}(P<0.01)$ and protein level $\times \mathrm{RS}(P<0.05)$.

between comet tail moment of colonocytes and mucus thickness ( $n$ 96, $r-0 \cdot 41, P=0 \cdot 001)$.

\section{Caecal and faecal SCFA}

Caecal and faecal acetate, butyrate, propionate and total SCFA pools were all increased by dietary RS (Table 4). Protein type also affected both caecal and faecal acetate, propionate, butyrate and total SCFA pools (Table 4) and rats fed RS showed significantly lower caecal and faecal $\mathrm{pH}(P<0 \cdot 001$; Table 2$)$. There was a significant correlation between caecal and faecal $\mathrm{pH}$ with respective total SCFA pools (caecal $r-0.81$, $P<0.0001$; faecal $r-0.67, P<0.0001)$. DNA damage as measured by the comet assay was found to be significantly associated with several caecal and faecal parameters. The significant relationships seen with DNA damage were with acetate pools (caecal $r-0.33, P<0.05$; faecal $r-0.35$, $P<0.05$ ), butyrate pools (faecal $r 0.34, P<0.05$ ) and total SCFA pools (caecal $r-0.402, P<0.001$; faecal $r-0.36$, $P<0 \cdot 05)$. In addition, a significant relationship was seen with mucus layer thickness and total SCFA pools (caecal $r$ 0.39, $P<0 \cdot 001$; faecal $r 0 \cdot 40, P<0 \cdot 001$ ).

\section{Discussion}

The present data confirm and extend our previous investigations on the effects of dietary protein level and RS on the colonic environment in rats. Specifically, we have shown again that increasing levels of dietary casein from $15 \%$ to $25 \%$ induces greater DNA strand breakage and thinning of the mucus layer. Up until now, we have only studied proteins of animal origin but these experiments show that a plant protein concentrate (soya) caused even greater colonocyte DNA damage than casein. Collectively, the data suggest that the basic effect was due to the protein content of the diet, rather than minor components such as haem (in meat) or 
phytochemicals (in soya). However, this does not explain the lack of a genetic damaging effect of higher dietary whey protein. A recent study showed that dietary exposure to both whey and soya proteins altered colonic global gene expression profiles, including repression of a key regulatory gene for cell cycle progression in rats with azoxymethane-induced colon tumours (Xiao et al. 2005). In addition, previous rodent studies, using colon tumour induction with azoxymethane or 1,2-dimethylhydrazine, showed that whey protein was protective compared to casein, red meat and soyabean diets (Hakkak et al. 2001a; McIntosh \& Le Leu, 2001; Belobrajdic et al. 2003). Another study demonstrated that bovine lactoferrin, a major whey component, reduced colon carcinogenesis in the post-initiation stage in azoxymethane-treated rats, with significant reduction of adenocarcinoma incidence (Tsuda et al. 2000). A suggested protective mechanism of whey is its capacity to increase tissue glutathione. Whey protein has been shown to raise hepatic and (to a lesser extent) colonic glutathione concentrations in rats (McIntosh et al. 1995) which may facilitate deactivation of xenobiotics via glutathione transferase activities (Bounous, 2000). Animal studies have shown that a fraction of dietary protein (resistant protein) escapes into the large bowel in a manner analogous to RS (Morita et al. 1998). A loss of protein from the small intestine has been reported in human subjects with ileostomy (McBurney et al. 1988). However, there seems to be no difference in the ileal digestibilities of cheese and beef protein which were 86-89\% (Silvester et al. 1997). This suggests that differences between proteins in the present study were due to other causes.

Another finding which has been replicated is attenuation of the DNA-damaging effect of casein by RS (Toden et al. 2005). Dietary fibre is important for large bowel function and studies in rodents with experimentally induced cancer have suggested that cereal fibres may be protective (Reddy, 2000). However, human studies have given quite contradictory findings. A large, multicentre prospective European study found a substantial $(30 \%)$ reduction in relative risk from the lowest to the highest strata of intake (Bingham et al. 2003). In contrast a metaanalysis of a number of prospective studies failed to find any protective effect of fibre (Asano \& McLeod, 2002). The expectations of a beneficial effect of fibre came from observations of low risk of colo-rectal cancer in populations who were consuming unrefined foods which were assumed to be high in dietary fibre. Subsequent analysis has shown some of these diets to be actually relatively low in fibre but high in RS (Topping \& Clifton, 2001) leading to higher large bowel SCFA. It appears highly possible that protection may be conferred by RS rather than NSP. The present data support this proposal as does the recent observation of a protective effect of RS against experimental cancer in rats (BauerMarinovic et al. 2006).

Despite the reduction with inclusion of RS, higher levels of DNA damage were found in rats fed soya. The present data are consistent with the increased colonic epithelial cell damage and increased proliferation with rats fed soya protein compared to rats fed casein (Govers et al. 1993) and also the increased tumour incidence and burden of dimethylhydrazine-induced intestinal tumour in rats compared to those fed whey or casein (McIntosh et al. 1995). The present experimental data are contrary to meta-analyses that suggest that there is an inverse correlation between consumption of non-fermented soya with colo-rectal cancer (Wu et al. 2000; 
Spector et al. 2003). The reasons for this difference are unclear as are those for the generally greater levels of damage with soya seen in this experiment. Minor soya components (e.g. saponins) are known to increase bile acid and steroid excretion (Lee et al. 2005) and secondary bile acids are thought to be cytotoxic within the large bowel (Narisawa et al. 1974).

The mechanism for the reduction of strand breaks by RS may lie in greater large bowel SCFA availability, especially of butyrate. While SCFA in general are thought to promote a favourable colonic environment, butyrate is thought to be especially important for mucosal integrity both as a metabolic fuel for colonocytes and also through specific actions which promote a normal cell phenotype (Rieger et al. 1999; Emenaker \& Basson, 2001). The sampling regime of the present experiment precluded the direct measurement of colonic SCFA. However, we did determine caecal and faecal SCFA as indirect measures of production and colonic exposure, respectively. As anticipated, the feeding of RS raised caecal SCFA, consistent with greater fermentation. No consistent relationship was found between the pools of total and individual SCFA and genetic damage. For example, SCFA and butyrate pools were low in rats fed casein and whey in the absence of RS. However, butyrate pools were significantly higher in those fed soya at both levels, i.e. where damage was greater. Similarly, both caecal total SCFA and butyrate were higher in rats fed RS independent of comet tail moment. The present data are similar to those noted earlier in man (Schwiertz et al. 2002; Muir et al. 2004) and animals (Le Leu et al. 2002; Annison et al. 2003; Bird et al. 2004) with various types of RS. Using faecal SCFA as an index of colonic exposure there was a similar lack of relationship between genetic damage and total and individual SCFA. However, faecal SCFA may not be an entirely appropriate measure of exposure as SCFA excretion can be affected by transit as well as production (Topping \& Clifton, 2001). Inter alia the present data support an interaction between undigested protein, RS and large bowel SCFA (Morita et al. 1998; Toden et al. 2005). The present data also suggest that the interactions between dietary protein, RS and genetic damage are complex. Other fermentation products and compounds present in the diet may have had a role in damage and/or repair (Rowland et al. 1985; Smith \& Macfarlane, 1996). In addition, previous studies have suggested that carcinogenic N-nitroso compounds, often found in large quantity in red and processed meat, may also have a strong role in damaging large bowel environment (Cross \& Sinha, 2004). Finally, there is a further interaction which remains to be explored, i.e. the microflora. The RS fed in the present experiment is known to be a prebiotic (Topping et al. 2003) and has also been shown to modify the activity of pathogenic organisms in vitro (Kleessen et al. 1997) and so could have led to changes in genetic damage and repair through modifying bacterial activity.

As noted previously (Toden et al. 2005), the mucus barrier was thinner in rats fed higher dietary casein in the absence of RS. A similar loss has been seen with high red meat diets (Toden et al. 2006) but was not observed with soya or whey. Feeding RS prevented this loss with casein and led to a generally thicker barrier. Previous studies suggest that SCFA increase colonic mucus secretion (Cummings \& Macfarlane, 1991; Shimotoyodome et al. 2000). Mucins, the main component of mucus, are encoded by MUC genes and several MUC genes are speculated to have links with colorectal cancer. Recently, Willemsen et al. (2003) used cell culture supernatant to demonstrate that SCFA differentially regulates prostaglandin production to stimulate mucin secretion via MUC2 expression in intestinal epithelial cells. However, it is possible also that the microflora may have interacted with diet to affect mucus thickness. Large bowel bacteria are known to possess mucinase activity (Dwarakanath et al. 1995) and alterations in this capability could have affected barrier thickness. This is also a potential explanation for the differential effects of whey and soya as neither of these led to the loss of mucus seen with casein. The reversal of the thinning of the mucus barrier by dietary protein by RS warrants further investigation. Loss of barrier function is a feature of inflammatory bowel disease and higher dietary protein has been related to loss of remission from ulcerative colitis (Jowett et al. 2004). RS has been shown to protect against experimental colitis (Moreau et al. 2003). While doubts have been cast on the relevance of this finding, there is an opportunity to determine the role of interactions between RS and other dietary components in this type of large bowel dysfunction.

The high and low ileal digestibility of the standard and high amylose maize starches, respectively, has been confirmed in rats with an effective ileostomy (Morita et al. 1999, 2004). The differences in large bowel variables with RS (greater digesta and faecal mass, lower $\mathrm{pH}$, greater caecal tissue weight) reflect this difference and accord with previous findings (Topping et al. 1997; Toden et al. 2005). Lower digesta $\mathrm{pH}$ is consistent with SCFA production leading to direct acidification and also utilisation of nitrogen (as $\mathrm{NH}_{4}^{+}$) for bacterial growth. Faecal pH values reflected those in the caecum, being lower in rats fed RS with values closer to 8 in rats fed the highly digestible starch. Lowering of $\mathrm{pH}$ is a possible contributor to some of the changes in genetic damage through reducing the bioavailability of potentially toxic biogenic agents. However, while this factor could have contributed to some of the observed effects, it was not a prime determinant as there was no significant relationship between $\mathrm{pH}$ and either genetic damage or mucus layer thickness.

As anticipated from previous studies (Topping et al. 1997; Toden et al. 2005), the mass of large bowel tissue was higher in rats fed RS than in those consuming the highly digestible starch. The greater length of the colon is also consistent with findings from pigs fed RS (Topping et al. 1997). These changes have been explained through a greater availability of SCFA as metabolic fuels.

In conclusion, we have demonstrated that casein, whey and soya proteins have differential effects on colonic DNA damage. Importantly, none of the effects were due to any differences in food intake or body weight. A moderately high level $(25 \%)$ of whey in the diet did not significantly increase the colonic DNA damage in comparison to $15 \%$ whey. Moreover, increased dietary casein and soya, particularly in the absence of RS and its fermentation products, appear to increase DNA damage in a rodent model. It appears likely that dietary proteins interact differently with RS in the colon because the SCFA differed among protein types when fed with RS. However, we have shown that including RS in the diet reduces colonic DNA damage regardless of the types of protein consumed. Further investigations are necessary to 
ascertain whether the proteins we have examined and RS exert similar effects in man.

\section{Acknowledgements}

The authors thank Dr Pat Buckley for helpful discussions.

\section{References}

Anderson D, Hambly RJ, Yu TW, Thomasoni F \& Shuker DE (1999) The effect of potassium diazoacetate on human peripheral lymphocytes, human adenocarcinoma Colon caco- 2 cells, and rat primary colon cells in the comet assay. Teratog Carcinog Mutagen 19, 137-146.

Annison G, Illman RJ \& Topping DL (2003) Acetylated, propionylated or butyrylated starches raise large bowel short-chain fatty acids preferentially when fed to rats. J Nutr 133, 3523-3528.

Asano T \& McLeod RS (2002) Dietary fibre for the prevention of colorectal adenomas and carcinomas. The Cochrane Database of Systematic Reviews 2002 CD003430.

Badger TM, Ronis MJ, Simmen RC \& Simmen FA (2005) Soy protein isolate and protection against cancer. $J$ Am Coll Nutr $\mathbf{2 4}$ 146S-149S.

Bauer-Marinovic M, Florian S, Muller-Schmehl K, Glatt H \& Jacobasch G (2006) Dietary resistant starch type 3 prevents tumor induction by 1,2-dimethylhydrazine and alters proliferation, apoptosis and dedifferentiation in rat colon. Carcinogenesis $\mathbf{2 7}$ $1849-1859$.

Belobrajdic DP, McIntosh GH \& Owens JA (2003) Whey proteins protect more than red meat against azoxymethane induced ACF in Wistar rats. Cancer Lett 198, 43-51.

Bingham SA, Day NE, Luben R, et al. (2003) Dietary fibre in food and protection against colorectal cancer in the European Prospective Investigation into Cancer and Nutrition (EPIC): an observational study. Lancet 361, 1496-1501.

Bird AR, Flory C, Davies DA, Usher S \& Topping DL (2004) A novel barley cultivar (Himalaya 292) with a specific gene mutation in starch synthase IIa raises large bowel starch and short-chain fatty acids in rats. $J$ Nutr 134, 831-835.

Bounous G (2000) Whey protein concentrate (WPC) and glutathione modulation in cancer treatment. Anticancer Res 20, 4785-4792.

Cassidy A, Bingham SA \& Cummings JH (1994) Starch intake and colorectal cancer risk: an international comparison. $\mathrm{Br} J$ Cancer 69, 937-942.

Chao A, Thun MJ, Connell CJ, McCullough ML, Jacobs EJ, Flanders WD, Rodriguez C, Sinha R \& Calle EE (2005) Meat consumption and risk of colorectal cancer. JAMA 293, 172-182.

Chen R, Rabinovitch PS, Crispin DA, Emond MJ, Bronner MP \& Brentnall TA (2005) The initiation of colon cancer in a chronic inflammatory setting. Carcinogenesis 26, 1513-1519.

Clausen MR \& Mortensen PB (1995) Kinetic studies on colonocyte metabolism of short chain fatty acids and glucose in ulcerative colitis. Gut 37, 684-689.

Cross AJ \& Sinha R (2004) Meat-related mutagens/carcinogens in the etiology of colorectal cancer. Environ Mol Mutagen 44, 44-55.

Cummings JH \& Macfarlane GT (1991) The control and consequences of bacterial fermentation in the human colon. $J$ Appl Bacteriol 70, 443-459.

Dwarakanath AD, Campbell BJ, Tsai HH, Sunderland D, Hart CA \& Rhodes JM (1995) Faecal mucinase activity assessed in inflammatory bowel disease using ${ }^{14} \mathrm{C}$ threonine labelled mucin substrate. Gut 37, 58-62.

Emenaker NJ \& Basson MD (2001) Short chain fatty acids differentially modulate cellular phenotype and c-myc protein levels in primary human nonmalignant and malignant colonocytes. Dig Dis Sci 46, 96-105.
Englyst H, Wiggins HS \& Cummings JH (1982) Determination of the non-starch polysaccharides in plant foods by gas-liquid chromatography of constituent sugars as alditol acetates. Analyst 107, 307-318.

Giovannucci E \& Willett WC (1994) Dietary factors and risk of colon cancer. Ann Med 26, 443-452.

Govers MJ, Lapre JA, De Vries HT \& Van der Meer R (1993) Dietary soybean protein compared with casein damages colonic epithelium and stimulates colonic epithelial proliferation in rats. J Nutr $\mathbf{1 2 3}$, 1709-1713.

Hakkak R, Korourian S, Ronis MJ, Johnston JM \& Badger TM (2001a) Dietary whey protein protects against azoxymethaneinduced colon tumors in male rats. Cancer Epidemiol Biomarkers Prev 10, 555-558.

Hakkak R, Korourian S, Ronis MJ, Johnston JM \& Badger TM (2001b) Soy protein isolate consumption protects against azoxymethane-induced colon tumors in male rats. Cancer Lett 166, $27-32$.

Helma C \& Uhl M (2000) A public domain image-analysis program for the single-cell gel-electrophoresis (comet) assay. Mutat Res 466, 9-15.

Jowett SL, Seal CJ, Pearce MS, Phillips E, Gregory W, Barton JR \& Welfare MR (2004) Influence of dietary factors on the clinical course of ulcerative colitis: a prospective cohort study. Gut 53, $1479-1484$

Kleessen B, Stoof G, Proll J, Schmiedl D, Noack J \& Blaut M (1997) Feeding resistant starch affects fecal and cecal microflora and short-chain fatty acids in rats. J Anim Sci 75, 2453-2462.

Larsson SC, Rafter J, Holmberg L, Bergkvist L \& Wolk A (2005) Red meat consumption and risk of cancers of the proximal colon, distal colon and rectum: the Swedish Mammography Cohort. Int $J$ Cancer 113, 829-834.

Le Leu RK, Hu Y \& Young GP (2002) Effects of resistant starch and nonstarch polysaccharides on colonic luminal environment and genotoxin-induced apoptosis in the rat. Carcinogenesis 23, 713-719.

Lee SO, Simons AL, Murphy PA \& Hendrich S (2005) Soyasaponins lowered plasma cholesterol and increased fecal bile acids in female golden syrian hamsters. Exp Biol Med (Maywood) 230, 472-478.

Lin Y, Meijer GW, Vermeer MA \& Trautwein EA (2004) Soy protein enhances the cholesterol-lowering effect of plant sterol esters in cholesterol-fed hamsters. J Nutr 134, 143-148.

Lupton JR (1995) Butyrate and colonic cytokinetics: differences between in vitro and in vivo studies. Eur J Cancer Prev 4, 373-378.

McBurney MI, Thompson LU, Cuff DJ \& Jenkins DJ (1988) Comparison of ileal effluents, dietary fibers, and whole foods in predicting the physiological importance of colonic fermentation. Am J Gastroenterol 83, 536-540.

McIntosh GH \& Le Leu RK (2001) The influence of dietary proteins on colon cancer risk. Nutr Res 21, 1053-1066.

McIntosh GH, Regester GO, Le Leu RK, Royle PJ \& Smithers GW (1995) Dairy proteins protect against dimethylhydrazine-induced intestinal cancers in rats. $J$ Nutr 125, 809-816.

Moreau NM, Martin LJ, Toquet CS, Laboisse CL, Nguyen PG, Siliart BS, Dumon HJ \& Champ MM (2003) Restoration of the integrity of rat caeco-colonic mucosa by resistant starch, but not by fructooligosaccharides, in dextran sulfate sodium-induced experimental colitis. Br J Nutr 90, 75-85.

Morita T, Kasaoka S, Hase K \& Kiriyama S (1999) Psyllium shifts the fermentation site of high-amylose cornstarch toward the distal colon and increases fecal butyrate concentration in rats. J Nutr 129, 2081-2087.

Morita T, Kasaoka S, Ohhashi A, Ikai M, Numasaki Y \& Kiriyama S (1998) Resistant proteins alter cecal short-chain fatty acid profiles in rats fed high amylose cornstarch. J Nutr 128, $1156-1164$ 
Morita T, Tanabe H, Takahashi K \& Sugiyama K (2004) Ingestion of resistant starch protects endotoxin influx from the intestinal tract and reduces D-galactosamine-induced liver injury in rats. $J$ Gastroenterol Hepatol 19, 303-313.

Muir JG, Yeow EG, Keogh J, Pizzey C, Bird AR, Sharpe K, O’Dea K \& Macrae FA (2004) Combining wheat bran with resistant starch has more beneficial effects on fecal indexes than does wheat bran alone. Am J Clin Nutr 79, 1020-1028.

Narisawa T, Magadia NE, Weisbuger JH \& Wynder EL (1974) Promoting effect of bile acids on colon carcinogenesis after intrarectal instillation of N-methyl-N'-nitro-N-nitrosoguanidine in rats. $J$ Natl Cancer Inst 53, 1093-1097.

National Health and Medical Research Council (2004) Australian code of practice for the care and use of animals for scientific purposes, 7th ed. (http://www.nhmc.gov.au/publications/synopses/ ea16syn.htm).

Norat T, Bingham S, Ferrari P, et al. (2005) Meat, fish, and colorectal cancer risk: the European Prospective Investigation into cancer and nutrition. J Natl Cancer Inst 97, 906-916.

Norat T, Lukanova A, Ferrari P \& Riboli E (2002) Meat consumption and colorectal cancer risk: an estimate of attributable and preventable fractions. IARC Sci Publ 156, 223-225.

Patten GS, Abeywardena MY, McMurchie EJ \& Jahangiri A (2002) Dietary fish oil increases acetylcholine- and eicosanoid-induced contractility of isolated rat ileum. J Nutr 132, 2506-2513.

Potter JD, Slattery ML, Bostick RM \& Gapstur SM (1993) Colon cancer: a review of the epidemiology. Epidemiol Rev 15, 499-545.

Reddy BS (2000) The Fourth DeWitt S. Goodman lecture. Novel approaches to the prevention of colon cancer by nutritional manipulation and chemoprevention. Cancer Epidemiol Biomarkers Prev 9, 239-247.

Rieger MA, Parlesak A, Pool-Zobel BL, Rechkemmer G \& Bode C (1999) A diet high in fat and meat but low in dietary fibre increases the genotoxic potential of 'faecal water'. Carcinogenesis 20, 2311-2316.

Ritzhaupt A, Ellis A, Hosie KB \& Shirazi-Beechey SP (1998) The characterization of butyrate transport across pig and human colonic luminal membrane. J Physiol 507, (Pt3), 819-830.

Rowland IR, Mallett AK \& Wise A (1985) The effect of diet on the mammalian gut flora and its metabolic activities. Crit Rev Toxicol 16, 31-103.

Schwiertz A, Lehmann U, Jacobasch G \& Blaut M (2002) Influence of resistant starch on the SCFA production and cell counts of butyrate-producing Eubacterium spp. in the human intestine. $J$ Appl Microbiol 93, 157-162.

Shaoul R, Okada Y, Cutz E \& Marcon MA (2004) Colonic expression of MUC2, MUC5AC, and TFF1 in inflammatory bowel disease in children. J Pediatr Gastroenterol Nutr 38, 488-493.

Shimotoyodome A, Meguro S, Hase T, Tokimitsu I \& Sakata T (2000) Short chain fatty acids but not lactate or succinate stimulate mucus release in the rat colon. Comp Biochem Physiol A Mol Integr Physiol 125, 525-531.

Silvester KR, Bingham SA, Pollock JR, Cummings JH \& O’Neill IK (1997) Effect of meat and resistant starch on fecal excretion of apparent N-nitroso compounds and ammonia from the human large bowel. Nutr Cancer 29, 13-23.

Smith EA \& Macfarlane GT (1996) Enumeration of human colonic bacteria producing phenolic and indolic compounds: effects of $\mathrm{pH}$, carbohydrate availability and retention time on dissimilatory aromatic amino acid metabolism. J Appl Bacteriol 81, 288-302.

Spector D, Anthony M, Alexander D \& Arab L (2003) Soy consumption and colorectal cancer. Nutr Cancer 47, 1-12.

Steinmetz KA \& Potter JD (1996) Vegetables, fruit, and cancer prevention: a review. J Am Diet Assoc 96, 1027-1039.

Toden S, Bird AR, Topping DL \& Conlon MA (2005) Resistant starch attenuates colonic DNA damage induced by higher dietary protein in rats. Nutr Cancer 51, 45-51.

Toden S, Bird AR, Topping DL \& Conlon MA (2006) Resistant starch prevents colonic DNA damage induced by high dietary cooked red meat or casein in rats. Cancer Biol Ther 5, 267-272.

Topping DL \& Clifton PM (2001) Short-chain fatty acids and human colonic function: roles of resistant starch and nonstarch polysaccharides. Physiol Rev 81, 1031-1064.

Topping DL, Fukushima M \& Bird AR (2003) Resistant starch as a prebiotic and synbiotic: state of the art. Proc Nutr Soc 62, 171-176.

Topping DL, Gooden JM, Brown IL, Biebrick DA, McGrath L, Trimble RP, Choct M \& Illman RJ (1997) A high amylose (amylomaize) starch raises proximal large bowel starch and increases colon length in pigs. $J$ Nutr 127, 615-622.

Tsuda H, Sekine K, Ushida Y, Kuhara T, Takasuka N, Iigo M, Han BS \& Moore MA (2000) Milk and dairy products in cancer prevention: focus on bovine lactoferrin. Mutat Res 462, 227-233.

Wacker M, Wanek P, Eder E, Hylla S, Gostner A \& Scheppach W (2002) Effect of enzyme-resistant starch on formation of 1,N(2)propanodeoxyguanosine adducts of trans-4-hydroxy-2-nonenal and cell proliferation in the colonic mucosa of healthy volunteers. Cancer Epidemiol Biomarkers Prev 11, 915-920.

Willemsen LE, Koetsier MA, van Deventer SJ \& van Tol EA (2003) Short chain fatty acids stimulate epithelial mucin 2 expression through differential effects on prostaglandin $\mathrm{E}(1)$ and $\mathrm{E}(2)$ production by intestinal myofibroblasts. Gut 52, 1442-1447.

Williamson SL, Kartheuser A, Coaker J, Kooshkghazi MD, Fodde R, Burn J \& Mathers JC (1999) Intestinal tumorigenesis in the Apc1638N mouse treated with aspirin and resistant starch for up to 5 months. Carcinogenesis 20, 805-810.

Wu AH, Yang D \& Pike MC (2000) A meta-analysis of soyfoods and risk of stomach cancer: the problem of potential confounders. Cancer Epidemiol Biomarkers Prev 9, 1051-1058.

Xiao R, Badger TM \& Simmen FA (2005) Dietary exposure to soy or whey proteins alters colonic global gene expression profiles during rat colon tumorigenesis. Mol Cancer 4, 1 . 